\title{
SINKRONISASI PENGATURAN SYARAT-SYARAT PENYERAHAN SEBAGIAN PELAKSANAAN PEKERJAAN KEPADA PERUSAHAAN LAIN SEBAGAI UPAYA PENINGKATAN PERLINDUNGAN HUKUM TERHADAP PEKERJA OUTSOURCING DI INDONESIA
}

\author{
Kadek Agus Sudiarawan \\ Fakultas Hukum Universitas Udayana
}

\begin{abstract}
ABSTRAK
Tujuan penelitian ini adalah untuk mengetahui bagaimana sinkronisasi pengaturan Syarat-Syarat Penyerahan Sebagian Pelaksanaan Pekerjaan Kepada Perusahaan Lain sebagai upaya peningkatan perlindungan hukum terhadap pekerja outsourcing di Indonesia, yaitu dengan mengkaji kesesuaian antara ketentuan dalam Permenakertrans RI No.19 Tahun 2012 dan SE Menakertrans RI No.04/MEN/VIII/2013 terhadap Putusan MK No.27/PUU-IX/2011.

Penelitian dilaksanakan dengan menggunakan metode yuridis normatif. Data yang digunakan dalam penelitian ini adalah data sekunder. Seluruh data yang terkumpul dianalisis dengan menggunakan metode kualitatif. Hasil penelitian ini disajikan dalam suatu laporan yang bersifat diskriptif analisis.

Hasil penelitian menunjukkan terdapat beberapa ketentuan dalam Permenakertrans dan SE Menakertrans seperti pengaturan prosedur dan syarat penyerahan pekerjaan kepada perusahaan lain, kewenangan asosiasi sektor usaha, mekanisme pendaftaran perusahaan, pengaturan pesangon dan sanksi yang secara substansial tidak sinkron dan cenderung melemahkan semangat peningkatan perlindungan hukum terhadap pekerja outsourcing sebagaimana amanat dari Putusan MK No.27/PUU-IX/2011.
\end{abstract}

Kata Kunci : Sinkronisasi, Penyerahan Sebagian Pekerjaan Kepada Perusahaan Lain, Perlindungan Hukum, Outsourcing

\section{ABSTRACT}

The purpose of this study is to know the synchronization of the rules of the requirements to transfer half of the works to other company. This stands as an effort to improve the legal protection of the outsourced workers in Indonesia by assessing the synchronization between the rules in Permenakertrans RI No.19 of 2012 (Permenakertrans) and SE Menakertrans RI No.04/MEN/VIII/2013 (SE Menakertrans) with the Decision of the Constitutional Court No. 27/PUU-IX/2011 (MK Decision).

This is a normative research that uses secondary data where all these data are analyzed using the qualitative methods. The report of this study is presented in a descriptive analysis way.

The results shows that there are some provisions, namely: the procedure and requirement to transfer the work to other company; authority of business sector association; mechanism to register a company; severance; and sanction, in Permenakertrans and SE Menakertrans, that substantially are not synchronize with Jurnal Komunikasi Hukum 
each other and tend to weaken the spirit to enhance the legal protection upon the outsourced workers as the mandate of the MK Decision.

Keywords: synchronization, transfer half of the works to other company, legal protection, outsourcing

\section{Pendahuluan}

Undang-Undang No.13 Tahun 2003 tentang Ketenagakerjaan (UU Ketenagakerjaan) secara khusus mengatur mengenai beberapa jenis perjanjian kerja yakni meliputi : Perjanjian Kerja Waktu Tertentu (PKWT), Perjanjian Kerja Waktu Tidak Tertentu (PKWTT) dan termasuk pula outsourcing. Pengaturan PKWT dan Outsourcing dalam UU Ketenagakerjaan dapat disebut sebagai upaya mewujudkan pasar kerja yang fleksibel di Indonesia yang ditujukan untuk perbaikan iklim investasi ditengah guncangan perekonomian pasca krisis finansial pada tahun 1997.

Terkait dengan hubungan kerja outsourcing, persaingan dunia bisnis yang begitu dinamis tentunya telah memaksa perusahaan untuk berkonsentrasi pada rangkaian proses atau aktivitas penciptaan produk dan jasa yang terkait dengan kompetensi utamanya. Konsekuensi logis dari strategi ini adalah keputusan perusahaan untuk mengalihdayakan atau menyerahkan proses-proses yang bukan merupakan core competence perusahaan tersebut kepihak lain dengan sistem yang disebut sebagai oustsourcing (Richardus Eko Indrajit, 2003).

Hubungan kerja melalui sistem outsourcing sering disebut sebagai bagian kapitalisme global yang cenderung merugikan pekerja. Prinsip utama pelaksaaan hubungan kerja Jurnal Komunikasi Hukum dengan pola ini yaitu pengusaha menghindari pekerja tetap dan menghindari hak-hak pekerja (Andari Yurikosari). Hubungan kerja outsourcing menjamin fokus organisasi perusahaan yang bekerja pada kegiatan inti tidak akan terpecah pada urusan atau kegiatan penunjang, sehingga organisasi inti dapat berkonsentrasi penuh mengerjakan kegiatan inti dengan semaksimal mungkin (Suwondo, 2003).

Secara tata bahasa, outsource berasal dari kata 'out' yang berarti di luar, dan kata 'source' yang berarti sumber. Penerjemah kemudian mengartikan outsource sebagai sumber dari luar, dan bila diaplikasikan ke dalam unit usaha berarti tenaga kerja yang diambil dari luar perusahaan atau alih daya (Aditya Warman, 2013). Dalam pengertian umum, istilah Outsourcing diartikan sebagai kegiatan membuat kontrak dengan perusahaan atau orang lain untuk melakukan fungsi tertentu (outsourcing is contracting with another company or person to do a particular function) (http:// www.sourcing.com). Didalam Black's Law Dictionary disebutkan outsourcing agreement is an agreement between a bussines and a service provider in which the service provider promises to provide necessary services, esp (Briyan A Garner, 2004).

Berdasarkan pengertian diatas, secara umum outsourcing dapat diartikan sebagai pendelegasian suatu Universitas Pendidikan Ganesha| 56 
kegiatan, aktivitas, operasi dan atau manajemen harian dari suatu proses bisnis perusahaan tertentu kepada pihak luar (perusahaan penyedia jasa pekerja atau buruh).

Dasar hukum dilegalkannya sistem outsourcing di Indonesia adalah dalam UU Ketenagakerjaan dengan pasal-pasal yang mengacu pada praktek outsourcing adalah Pasal 64, 65 dan 66. Dimana secara khusus diatur dalam sistem outsourcing perusahaan dapat menyerahkan sebagian pelaksanaan pekerjaan kepada perusahaan lainnya melalui 2 mekanisme yaitu : perjanjian pemborongan pekerjaan atau perjanjian penyediaan jasa pekerja/buruh

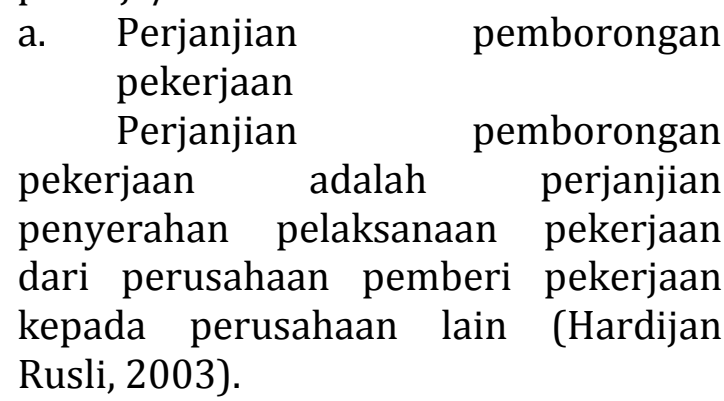

Perjanjian pemborongan pekerjaan harus dibuat secara tertulis dan pekerjaan yang dapat diserahkan kepada perusahaan lain harus memenuhi syarat-syarat sebagai berikut :

a. Dilakukan secara terpisah dari kegiatan utama,

b. Dilakukan dengan perintah langsung atau tidak langsung dari pemberi kerja,

c. Merupakan kegiatan penunjang perusahaan secara keseluruhan,

d. Tidak menghambat proses produksi secara langsung.

Dalam hal pekerjaan yang diserahkan tidak memenuhi Jurnal Komunikasi Hukum persyaratan yang ditentukan diatas, maka hubungan kerja antara pekerja dengan perusahaan penerima pemborongan beralih menjadi hubungan kerja pekerja tersebut dengan perusahaan pemberi pekerjaan. b. Perjanjian penyediaan jasa pekerja/buruh

Perusahaan tidak diperbolehkan memperkerjakan pekerja dari penyedia jasa pekerja untuk melaksanakan pekerjaan yang berhubungan dengan kegiatan usaha pokok atau kegiatan yang berhubungan langsung dengan proses produksi. Pekerja atau buruh dari perusahaan penyedia jasa pekerja hanya boleh digunakan untuk kegiatan jasa penunjang atau kegiatan yang tidak berhubungan langsung dengan proses produksi. Kegiatan tersebut antara lain : usaha pelayanan kebersihan (cleaning service), usaha penyediaan makanan bagi pekerja/buruh (catering), usaha tenaga pengamanan (security/satuan pengamanan), usaha jasa penunjang dipertambangan dan perminyakan, serta usaha penyediaan angkutan pekerja/buruh.

Pengaturan outsourcing dalam UU Ketenagakerjaan, pada satu sisi telah membuka peluang munculnya perusahaan-perusahaan baru yang bergerak dibidang jasa, dan disisi lain memungkinkan perusahaanperusahaan yang telah berdiri untuk melakukan efisiensi dengan memanfaatkan outsourcing untuk memproduksi barang atau jasa yang tidak berhubungan langsung dengan bisnis utama perusahaan (Markeling, 2009).

Upaya pekerja untuk melawan sistem outsourcing dan PKWT seakan Universitas Pendidikan Ganesha| 57 
tidak pernah berhenti. Salah satu langkah yang diambil pekerja yaitu melalui permohonan dengan register No.27/PUU-IX/2011 yang diajukan oleh saudara Didik Supriadi mewakili Aliansi Petugas Pembaca Meter Listrik Indonesia (AP2MLI). Judicial review diajukan terhadap ketentuan Pasal 59, Pasal 64, Pasal 65 dan Pasal 66 UU Ketenagakerjaan.

Atas permohonan tersebut, pada tanggal 17 Januari 2012 MK menjatuhkan Putusan MK No.27/PUUIX/2011. MK memandang bahwa PKWT sebagaimana diatur dalam Pasal 59 UU Ketenagakerjaan itu tidak bertentangan dengan UUD NRI 1945. Disisi lain pengaturan mengenai outsourcing yang terkandung dalam ketentuan Pasal 65 dan 66 UU Ketenagakerjaan oleh MK kemudian dipertimbangkan lebih jauh mengenai apakah ketentuan-ketentuan dalam norma dimaksud menyebabkan terancamnya hak setiap orang dan hak-hak pekerja outsourcing yang diberikan perlindungan atau dijamin dalam UUD NRI 1945, yaitu hak untuk bekerja dan mendapatkan imbalan serta perlakuan yang layak dalam hubungan kerja sebagaimana diatur dalam Pasal 28D ayat (2) dan hak setiap warga negara atas pekerjaan dan penghidupan yang layak bagi kemanusiaan seperti yang diatur dalam Pasal 27 ayat (2) UUD NRI 1945 (I Dewa Gede Palguna, 2012).

Dalam menjawab pertanyaan tersebut MK pertama-tama merujuk pertimbangan Mahkamah sendiri dalam Putusan MK No.12/PUU-I/2003 yang pada dasarnya menyatakan bahwa outsourcing tidaklah terbukti jika dikatakan sebagai bentuk Jurnal Komunikasi Hukum perbudakan modern dalam proses produksi. Pada Putusan MK N0.27/PUU-IX/2011, meskipun tidak bergeser dari pendiriannya bahwa outsourcing tidak bertentangan dengan UUD NRI 1945, namun Mahkamah menekankan pentingnya perlindungan kepada pekerja outsourcing akan pemenuhan hak-hak konstitusionalnya yang dijamin oleh Pasal 28D ayat (2) dan Pasal 27 ayat (2) UUD NRI 1945.

Semangat Perlindungan pekerja ini tampak jelas dalam pertimbangan hukum MK yang menyatakan antara lain :

frasa"...untuk menghindari perusahaan melakukan eksploitasi pekerja/buruh hanya untuk keuntungan bisnis tanpa memperhatikan jaminan dan perlindungan atas hak-hak pekerja/buruh untuk mendapatkan pekerjaan dan upah yang layak, dan untuk meminimalisasi hilangnya hakhak konstitusional para pekerja outsourcing, Mahkamah perlu menentukan perlindungan dan jaminan hak bagi pekerja/buruh. Dalam hal ini dua model yang dapat dilaksanakan untuk melindungi hak-hak pekerja/buruh. Pertama, dengan mensyaratkan agar perjanjian kerja antara pekerja/buruh dengan perusahaan yang melaksanakan pekerjaan outsourcing tidak berbentuk PKWT, melainkan berbentuk "perjanjian kerja waktu tidak tertentu". Kedua, menerapkan prinsip pengalihan tindakan perlindungan bagi pekerja/buruh (Tranfers of Undertaking Protection of Employment atau TUPE) yang bekerja pada perusahaan yang melaksanakan outsourcing.

Pemberlakuan model pertama menegaskan hubungan kerja Universitas Pendidikan Ganesha| 58 
antara pekerja dengan perusahaan yang melaksanakan pekerjaan outsourcing adalah konstitusional sepanjang dilakukan berdasarkan model "perjanjian kerja waktu tidak tertentu secara tertulis. Model yang kedua diterapkan, dalam hal hubungan kerja antara pekerja dengan perusahaan yang melaksanakan perkerjaan outsourcing melalui PKWT maka pekerja harus tetap mendapat perlindungan atas haknya sebagai pekerja dengan menerapkan prinsip pengalihan perlindungan bagi pekerja atau buruh (Tranfers of Undertaking Protection of Employment atau TUPE) yang bekerja pada perusahaan yang melaksanakan pekerjaan outsourcing. TUPE sebagai prinsip pengalihan perlindungan bagi pekerja yang menekankan bahwa jika berganti perusahaan outsourcing masa kerja pekerja tetap sebagai masa kerja yang diperhitungkan oleh perusahaan outsourcing baru dan harus dijamin diterima oleh perusahaan outsourcing baru dengan dijamin kelangsungan bekerjanya dengan kompensasi yang sama (Muhammad Aditya Warman).

Langkah taktis lanjutan yang dilakukan pemerintah pasca Putusan MK No.27/PUU-IX/2011 terkait dengan upaya peningkatan perlindungan pekerja outsourcing adalah dengan membuat guidance atau aturan pelaksana pelaksanaan outsourcing. Peraturan Menteri Tenaga Kerja dan Transmigrasi Republik Indonesia Nomor.19 Tahun 2012 tentang Syarat-Syarat Penyerahan Sebagian Pelaksanaan Pekerjaan Kepada Perusahaan Lain (Permenakertrans 19/2012) dan Surat Edaran Menteri Tenaga Kerja dan Jurnal Komunikasi Hukum
Transmigrasi Republik Indonesia No.04/MEN/VIII/2013

(SE Menakertrans 04/2013) kemudian hadir sebagai tindak lanjut pemerintah terhadap Putusan MK. Salah satu isu hangat yang muncul pasca dikeluarkannya aturan ini ialah perusahaan kemudian harus menanggung biaya besar dan tidak dapat melakukan efisiensi lagi, beberapa perusahaan bahkan terancam akibat pengetatan syarat dari pemerintah di dalam Permenakertrans (http://www.tribunnews.com,).

Permenakertrans No.19/2012 dan SE Menakertrans 04/2013 ini hadir dan melakukan beberapa perubahan atas UU Ketenagakerjaan seperti perubahan pada penjelasan pasal 66 ayat (1). Proses perubahan undang-undang ini tidak dlakukan dengan prosedur yang sama dengan ketentuan diatas. Ketentuan lainnya yang diatur oleh Permenakertrans ini adalah dalam bentuk pelaksanaan penetapan jenis kegiatan utama dan pendukung di perusahaan.

Dalam kaitannya dengan perlindungan hukum terhadap pekerja outsourcing, Permenakertrans No.19/2012 juga mengatur perubahan mendasar terkait hubungan kerja pekerja outsourcing dalam bentuk diisyaratkan adanya pengalihan perlindungan hak-hak pekerja yang obyek kerjanya tetap ada, jika hubungan kerjanya diikat dengan PKWT.

Hal ini sejatinya menunjukkan semangat yang diemban dari lahirnya Permenakertrans No.19/2012 dan SE Menakertrans 04/2013 tidak lain adalah ditujukan untuk perbaikan dalam pengaturan kegiatan utama dan Universitas Pendidikan Ganesha| 59 
penunjang serta melakukan perbaikan dalam pengaturan tentang hubungan kerja pekerja outsourcing di Indonesia. Namun faktanya pelaksanaan dilapangan kemudian malah menunjukkan munculnya berbagai kebingungan-kebingungan baru dan beberapa celah hukum yang dapat dimanfaatkan oleh pihak pengusaha atau perusahaan outsourcing untuk tidak segera memperbaiki sistem dan tata kelola perusahaannya agar lebih mampu melindungi pekerja sebagaimana semangat dari Putusan MK No.27/PUU-IX/2011.

Sinkronisasi pengaturan syaratsyarat penyerahan sebagian pelaksanaan pekerjaan kepada perusahaan lain dalam Permenakertrans No.19/2012 dan SE Menakertrans No.04/2013 dengan semangat perlindungan pekerja dalam Putusan MK No.27/PUU-IX/2011 menjadi begitu penting dalam upaya meningkatkan perlindungan hukum terhadap pekerja outsourcing.

Berangkat dari latar belakang tersebut diatas maka penulis tertarik untuk melakukan penelitian hukum dalam lingkup hukum ketenagakerjaan Indonesia untuk berusaha menemukan bagaimana "Sinkronisasi Pengaturan Syarat-Syarat Penyerahan Sebagian Pelaksanaan Pekerjaan Kepada Perusahaan Lain Sebagai Upaya Peningkatan Perlindungan Hukum Terhadap Pekerja Outsourcing di Indonesia".

\section{Pembahasan}

Sinkronisasi Materi Muatan Permenakertrans RI No.19/2012 dan SE Menakertrans RI No.04/2013 terhadap Semangat Penguatan Jurnal Komunikasi Hukum
Perlindungan Hukum Terhadap Pekerja Outsourcing dalam Putusan MK No.27/PUU-IX/2011

Dalam rangka mengukur tingkat sinkronisasi antara materi muatan didalam Permenakertrans No.19/2012 dan SE Menakertrans No.4/2013 terhadap Putusan MK No.27/PUUIX/2011 jo UU No.13 Tahun 2003, maka harus dibangun indikatorindikator khusus yang merupakan bagian dari muatan dari Permenakertrans dan SE untuk kemudian dapat dianalisis tingkat kesesuaiannya dengan semangat penguatan perlindungan hukum terhadap pekerja outsourcing dalam Putusan Mahkamah Konstitusi No.27/PUU-IX/2011.

Adapun beberapa point muatan Permenakertrans No.19/2013 dan SE Menakertrans No.04/2013 yang kemudian dianalisis kesesuaiannya terhadap Putusan MK No.27/PUUIX/2011 antara lain meliputi :

a. Bagian Konsideran

Pada bagian konsideran, Permenaker outsourcing ini merujuk pada UU No.3 Tahun 1951 tentang Pernyataan Berlakunya UndangUndang Pengawasan Perburuhan Nomor 23 Tahun 1948, UU No.13 Tahun 2003 tentang Ketenagakerjaan, UU No. 2 Tahun 2004 tentang Penyelesaian Perselisihan Hubungan Industrial dan Keppres No.84/P Tahun 2009.

Pada bagian konsideran dijelaskan pula bahwa 2 (dua) Kepmenakertrans yang mengatur mengenai outsourcing sebelumnya dinilai sudah tidak sesuai dengan perkembangan saat ini, sehingga perlu dilakukan penyempurnaan. Universitas Pendidikan Ganesha| 60 
Kepmenakertrans tersebut adalah Kepmenakertrans No.KEP.101/MEN/VI/2004 tentang Tata Cara Perijinan Penyediaan Jasa Pekerja/Buruh dan Kepmenakertrans No.KEP.220/MEN/X/2004 tentang Syarat-Syarat Penyerahan Sebagian Pelaksanaan Pekerjaan kepada Perusahaan Lain.

Analisis yang timbul bila memperhatikan konsideran dan ketentuan penutup tersebut, Permenakertrans No.19/2012 bukanlah aturan perubahan dari kedua Kepmenakertrans tersebut melainkan merupakan aturan pengganti. Maka semua ketentuan dalam dua Kepmenakertrans tersebut tidak lagi berlaku sebagai hukum positif.

\begin{tabular}{lrr}
\multicolumn{1}{c}{ Pada } & bagian & lainnya, \\
pemerintah & justru & tidak \\
mencantumkan & Putusan & MK \\
No.27/PUU-IX/2011 & kedalam \\
konsideran & & munculnya
\end{tabular}

Permenakertrans ini. Padahal tidak dapat dibantah lagi bahwa Putusan MK sangat mempengaruhi munculnya Permenakertrans outsourcing ini. Ketentuan dalam Pasal 29 dan Pasal 31 Permenakertrans No.19/2012 merupakan beberapa pengaturan substansial yang dipengaruhi langsung oleh Putusan MK.

Ketentuan Pasal 29 mengatur mengenai hubungan kerja antara perusahaan penyedia jasa pekerja dengan pekerja yang dapat didasarkan atas PKWTT atau PKWT. Pada ayat 2 diatur mengenai dalam hal hubungan kerja didasarkan atas PKWT yang obyeknya tetap ada sekurangkurangnya harus memuat jaminan kelangsungan bekerja, jaminan terpenuhinya hak-hak pekerja sesuai Jurnal Komunikasi Hukum dengan perundang-undangan, dan jaminan perhitungan masa kerja apabila terjadi pergantian perusahaan penyedia jasa pekerja untuk menetapkan upah. Dalam ayat 3 kemudian diatur secara khusus mengenai hak-hak pekerja. Pengaruh dari Putusan MK No.27/PUU-IX/2011 juga terlihat dari ketentuan Pasal 31 Permenakertrans ini yang mengatur mengenai tindakan atau jalur yang dapat ditempuh pekerja bila tidak memperoleh jaminan kelangsungan pekerja. Ketentuan Pasal 29 dan Pasal 31 Permenakertrans ini tidak lain merupakan aplikasi dari kewajiban pengaturan prinsip pengalihan perlindungan hak pekerja (TUPE) sebagai upaya perlindungan hukum terhadap pekerja outsourcing berdasarkan PKWT yang merupakan salah satu intisari dari Putusan MK. Tidak dicantumkannya Putusan MK No.27/PUU-IX/2011 sebagai salah satu dasar pembentukan aturan pelaksana ini juga ditemukan dalam SE Menakertrans No.04/2013 yang merupakan aturan pelaksanaan dari Permenakertrans No.19/2012. Pilihan Menakertrans untuk tidak mencantumkan Putusan MK sebagai konsideran dan atau pada pendahuluan aturan pelaksana ini memberi kesan bahwa pembentukan Permenakertrans dan SE sebagai inisiatif murni Kemenakertrans dan bukan merupakan pengaruh dari Putusan MK No.27/PUU-IX/2011 ataupun atas desakan masyarakat (pekerja) (http//:www.pemantaukeadilan).

b. Bagian Substansi Pasal-Pasal dalam Permenakertrans dan SE

Universitas Pendidikan Ganesha| 61 
1. Prosedur dan Syarat-Syarat Penyerahan Pekerjaan Kepada Perusahaan Lain.

Ketentuan terkait prosedur dan syarat-syarat penyerahan pekerjaan kepada perusahaan lain dalam Permenakertrans No.19/2019 tidak berbeda dengan UU Ketenagakerjaan. Penyerahan pekerjaan kepada perusahaan lain itu dapat dilakukan melalui pemborongan pekerjaan atau melalui perjanjian penyediaan jasa pekerja.

Sistematika teknis dalam penyerahan pekerjaan melalui pemborongan pekerjaan, mensyaratkan pemberi kerja harus terlebih dahulu menentukan bidang mana dari proses kegiatan perusahaannya yang dikategorikan sebagai pekerjaan penunjang. Ketentuan Pasal 65 ayat (2) UU Ketenagakerjaan mengatur empat syarat pekerjaan yang boleh diborongkan kepada perusahaan lain. Keempat syarat itu meliputi :

a. pekerjaan yang dikerjakan itu dilakukan secara terpisah dari kegiatan utama.

b. pekerjaan yang dilakukan dengan perintah langsung atau tidak langsung dari pemberi kerja.

c. pekerjaan itu merupakan kegiatan penunjang perusahaan secara keseluruhan.

d. pekerjaan yang diborongkan tidak menghambat proses produksi secara langsung.

Pemerintah dalam

Permenakertrans No.19/2012 kemudian memberi penjelasan khusus terhadap keempat syarat diatas. Penjelasan tersebut membuat Permenakertrans tersebut identik Jurnal Komunikasi Hukum bukan sebagai ketentuan pokok tetapi sebagai ketentuan penjelasan.

Ketentuan Pasal 3 ayat (2)

Permenakertrans No.19/2012 selengkapnya disusun dengan pemaparan bahwa pekerjaan yang dapat diserahkan kepada perusahaan penerima pemborongan sebagaimana dimaksud pada ayat (1) harus memenuhi syarat sebagai berikut :

a. dilakukan secara terpisah dari kegiatan utama baik manajemen maupun kegiatan pelaksanaan pekerjaan,

b. dilakukan dengan perintah langsung atau tidak langsung dari pemberi pekerjaan, dimaksudkan untuk memberi penjelasan tentang cara melaksanakan pekerjaan agar sesuai dengan standar yang ditetapkan oleh perusahaan pemberi pekerjaan,

c. merupakan kegiatan penunjang perusahaan secara keseluruhan artinya kegiatan tersebut merupakan kegiatan yang mendukung dan memperlancar pelaksanaan kegiatan utama sesuai dengan aluru kegiatan pelaksanaan pekerjaan yang ditetapkan oleh asosiasi sektor usaha yang dibentuk sesuai peraturan perundang-undangan,

d. tidak menghambat proses produksi secara langsung yang diartikan sebagai kegiatan tersebut merupakan kegiatan tambahan yang apabila tidak dilakukan oleh perusahaan pemberi pekerjaan, proses pelaksanaan pekerjaan tetap berjalan sebagaimana mestinya.

Pengaturan ketentuan penjelasan tersebut kemudian memunculkan Universitas Pendidikan Ganesha| 62 
berbagai tafsir baru yang menimbukan kebingungan dalam tahap pelaksanaannya. Penentuan kategori yang termasuk pekerjaan penunjang yang dapat ditentukan oleh asosiasi sektor usaha menjadi salah satu permasalahan yang menimbulkan berbagai polemik di masyarakat. Padahal UU Ketenagakerjaan sebelumnya telah memberikan spesifikasi khusus sebagai syarat pemborongan pekerjaan. Pemerintah seharusnya tidak boleh membuat secara sepihak penjelasan baru atas undang-undang, terlebih memasukkan ke dalam peraturan menteri, kecuali undang-undang memberikan mandat atau arahan kepada eksekutif untuk melakukan itu (Juanda Pangaribuan).

SE Menakertrans No.04/2013 ikut memperkeruh pengaturan tentang outsourcing tersebut. Ketentuan pada SE menyebutkan bahwa pemborongan boleh dilakukan di lokasi kantor atau di lokasi perusahaan pemberi kerja. Pengaturan tersebut menandakan bahwa pembuat kebijakan tidak memahami apa itu pemborongan pekerjaan dalam sistem ketenagakerjaan. UU Ketenagakerjaan telah tegas menentukan bahwa pemborongan pekerjaan harus dilakukan terpisah dari kegiatan utama (http://www.jawapos.com,).

Ratio legis UU Ketenagakerjaan mengharuskan pemborongan pekerjaan dilakukan di luar kantor atau lingkungan perusahaan karena pemborongan pekerjaan merupakan pengalihan pekerjaan, bukan pengalihan pekerja (orang). Ketentuan SE Menakertrans No.04/2013 yang memperbolehkan pemborongan orang, dapat diklasifikasikan sebagai bentuk Jurnal Komunikasi Hukum dari perbudakan yang dilegalkan. Celah hukum ini akan mengakibatkan terjadinya berbagai pelanggaran seperti banyaknya perusahaan yang tidak memenuhi ketentuan sebagai perusahaan penyedia jasa yang tidak mengaku sedang melakukan usaha outsourcing, melainkan hanya melakukan memborongkan pekerjaan tersebut.

2. Kewenangan Asosiasi Sektor Usaha

Ketentuan Pasal 3 ayat (2) huruf (c) Permenakertrans No.19/2012 menyebutkan bahwa asosiasi sektor usaha sebagai lembaga yang berwenang menetapkan alur kegiatan proses pelaksanaan pekerjaan perusahaan.

Konsep pembuatan alur proses sesungguhnya adalah mengacu kepada strategi perusahaan guna meningkatkan daya saingnya. Dasar pertimbangan perusahaan dalam mengalihkan sebagaian pekerjaan kepada perusahaan lain adalah untuk fokus pada bisnis utama, perampingan organisasi dan peningkatan produktifitas. Hal ini berimplikasi pada besarnya kemungkinan asosiasi akan membuat alur proses sebatas kebutuhan dan kepentingan bisnis mereka. Pengaturan kewenangan asosiasi sektor usaha dalam Permenakertrans No.19/2012 dianggap telah memberikan blangko kepada pengusaha untuk dengan sendirinya menentukan sektor-sektor usaha tersebut. Pengusaha tentu akan menentukan sebanyak mungkin pekerjaan yang masuk dalam kegiatan penunjang agar bisa sebanyakbanyaknya dilakukan melalui 
pemborongan pekerjaan (Hadi Shubhan).

Pemerintah

perlu

memperhatikan dan memastikan sejauh mana legalitas asosiasi dan kekuatan hukum yang menyertainya dan secara khusus memberikan acuan agar asosiasi sektor usaha tidak dianggap membuat alur proses sebatas kebutuhan dan kepentingan bisnis mereka. Ketika pemerintah memandang perlu memberikan kewenangan kepada asosiasi sektor usaha menentukan alur kegiatan bisnis perusahaan, penjelasan Pasal 3 ayat (2) seharusnya dibuat dalam amandemen UU Ketenagakerjaan atau setidaknya disusun ke dalam pasal tersendiri yang terpisah dari Pasal 3 ayat (2) (Hadi Shubhan).

3. Status Badan Hukum Bagi Perusahaan Outsourcing

Permenakertrans No.19/2012 menentukan bahwa perusahaan yang dapat menerima pemborongan pekerjaan adalah perusahaan berbadan hukum. Klasifikasi yang dapat digolongkan ke dalam badan hukum adalah Perseroan Terbatas (PT), yayasan dan koperasi. Permenakertrans kemudian tidak menyebut PT sebagai satu-satunya perusahaan yang bertindak sebagai penerima atau pemborongan pekerja.

Berbeda dengan ketentuan

Pasal 24 ditegaskan bahwa perusahaan yang dapat bertindak sebagai perusahaan penyedia jasa pekerja adalah perusahaan berbentuk Perseroan Terbatas (PT). Ketentuan tersebut secara tidak langsung menganggap koperasi, yayasan, firma, $\mathrm{CV}$ tidak dapat bertindak dalam perjanjian penyedia jasa pekerja. Jurnal Komunikasi Hukum
Konsekuensi hukum apabila perjanjian penyedia jasa pekerja bukan berbentuk PT, maka hubungan kerja pekerja outsourcing berdasarkan Pasal 66 ayat (3) dan ayat (4) UU Ketenagakerjaan beralih ke perusahaan pengguna.

Ketentuan terkait keharusan perusahaan penyedia jasa pekerja harus berbentuk PT secara khusus memang memiliki nilai positif yaitu untuk memastikan perusahaan tersebut siap secara finansial dan organisasi dalam mengelola perusahaannya sehingga mampu melindungi hak-hak pekerjanya. Hal ini akan berimplikasi pada peningkatan perlindungan hukum terhadap pekerja outsourcing di Indonesia.

4. Mekanisme Pendaftaran Perusahaan

Ketentuan Pasal 10 Ayat (1) dan Pasal 20 ayat (1) Permenakertrans No.19/2012 mewajibkan pengusaha mendaftarkan perjanjian pemborongan dan perjanjian penyediaan jasa pekerja ke kantor pemerintahan yang mengurusi ketenagakerjaan di kabupaten/kota.

Pendaftaran perjanjian penyediaan jasa pekerja ditentukan paling lambat dilakukan 30 hari kerja sejak ditandatangani perjanjian tersebut. Ketentuan ini juga mengatur untuk perjanjian pemborongan harus didaftarkan paling lambat 30 hari kerja sebelum pekerjaan dilaksanakan. Permenaker tidak menjelaskan apa tujuan mendaftarkan perjanjian borongan pekerjaan. Pendaftaran perjanjian borongan dan perjanjian penyediaan jasa tenaga kerja dikualifikasikan sebagai sarana memeriksa implementasi Pasal 5, Pasal Universitas Pendidikan Ganesha| 64 
9, Pasal 17, Pasal 20, Pasal 24 Permenakertrans No.19/2012.

Permenakertrans juga tidak mengatur sanksi kepada perusahaan pemberi pekerjaan dan penerima pekerjaan yang tidak mendaftarkan perjanjian pemborongan. Permenakertrans hanya mengatur akibat hukum bagi perusahaan yang memborongkan pekerjaan sebagaimana diatur dalam Pasal 7 ayat (2) yang menegaskan, hubungan kerja antara penerima pemborongan dengan pekerja beralih kepada perusahaan pemberi pekerjaan bila terbukti penyerahan pekerjaan itu dilakukan sebelum memiliki bukti pelaporan.

Bagian lain ketentuan Pasal 22 melarang perusahaan penyedia jasa pekerja melaksanakan operasional perusahaan sebelum memiliki bukti pendaftaran perjanjian penyediaan jasa pekerja. Apabila penyediaan jasa pekerja tetap melaksanakan operasionalnya, dinas tenaga kerja tingkat propinsi mencabut izin operasional penyediaan jasa pekerja.

Pada keadaan tersebut Permenakertrans No.19/2012 tidak menyebutkan hubungan kerjasama perjanjian penyedia jasa pekerja dengan perusahaan pemberi kerja berakhir demi hukum. Ketentuan Pasal 23 ayat (2) mengatur bahwa pemenuhan hak pekerja tetap menjadi tanggung jawab perjanjian penyediaan jasa pekerja. Hal ini berkonsekuensi pada kondisi bahwa pencabutan izin operasional perjanjian penyediaan jasa pekerja tidak serta merta mengakhiri kontrak kerja antara perjanjian penyedia jasa pekerja. Pencabutan izin operasional hanya memberi derita bagi pekerja perjanjian penyediaan jasa Jurnal Komunikasi Hukum pekerja tetapi tidak memberi manfaat kepada pekerja (Juanda Pangaribuan).

5. Hak Menerima Ganti Rugi atau Pesangon.

Ketentuan Pasal 29

Permenakertrans merupakan salah satu pengaturan substansial yang dipengaruhi langsung oleh Putusan MK No.27/PUU-IX/2011. Ketentuan Pasal 29 mengatur mengenai hubungan kerja antara perusahaan penyedia jasa pekerja dengan pekerja yang dapat didasarkan atas PKWTT atau PKWT. Dalam ketentuan ayat 2 diatur pula mengenai dalam hal hubungan kerja didasarkan atas PKWT yang obyeknya tetap ada sekurang-kurangnya harus memuat jaminan kelangsungan bekerja, jaminan terpenuhinya hak-hak pekerja sesuai dengan perundangundangan, dan jaminan perhitungan masa kerja apabila terjadi pergantian perusahaan penyedia jasa pekerja untuk menetapkan upah. Sebagai bentuk perlindungan terhadap pekerja dalam ayat 3 kemudian diatur secara khusus mengenai hak-hak pekerja yang diantaranya meliputi : hak atas cuti, hak atas jaminan sosial, hak atas tunjangan hari raya, hak istirahat paling singkat 1 hari dalam 1 minggu, hak menerima ganti rugi dalam hal hubungan kerja diakhiri oleh perusahaan penyedia jasa, hak atas penyesuaian upah terhadap masa kerja.

Permenakertrans No.19/2012 juga secara khusus menyebutkan bahwa jika pelaksanaan berdasarkan PKWT sekurang-kurangnya harus memuat: jaminan kelangsungan bekerja, jaminan terpenuhinya hak-hak pekerja dan jaminan masa kerja untuk Universitas Pendidikan Ganesha| 65 
menetapkan

upah

(http://disnakertrans.kaltimprov.com).

Pengaturan ini kemudian masih menimbukan kebingungan dari pelaku hubungan industrial khususnya oleh sebagian besar pengusaha atau perusahaan outsourcing. Keluhan pengusaha ialah terkait ketidakjelasan pengaturan antara Permenakertrans dengan UU Ketenakerjaan terkait ganti rugi atau pesangon untuk pekerja dalam hal hubungan kerja diakhiri perusahaan penyedia jasa pekerja. Ketentuan Pasal 29 ayat 3 point e Permenakertrans No.19/2012 menyebutkan bahwa pekerja berhak menerima ganti rugi dalam hal hubungan kerja diakhiri oleh perusahaan penyedia jasa pekerja sebelum perjanjian kerja waktu tertentu berakhir bukan karena kesalahan pekerja. Ketentuan ini memang relatif tidak berbeda dengan ketentuan Pasal $62 \quad$ UU Ketenagakerjaan yang mengatur bahwa apabila salah satu pihak mengakhiri hubungan kerja sebelum berakhirnya jangka waktu yang ditetapkan dalam perjanjian kerja waktu tertentu, pihak yang mengakhiri hubungan kerja diwajibkan membayar ganti rugi kepada pihak lainnya sebesar upah pekerja sampai batas waktu berakhirnya jangka waktu perjanjian kerja.

\section{Sanksi}

Ketentuan BAB V SE Menakertrans No.04/2013 secara khusus mengatur mengenai sanksi. Pelanggaran terhadap ketentuan Permenakertrans 19/2012 tentang syarat-syarat penyerahan sebagian pelaksanaan pekerjaan kepada Jurnal Komunikasi Hukum perusahaan lain, dikenakan sanksi berupa :

a. Beralihnya hubungan kerja pekerja dari perusahaan penerima pemborongan kepada pemberi kerja dalam hal perusahaan pemberi pekerjaan menyerahkan sebagian pelaksanaan perkerjaan kepada perusahaan lain tanpa bukti pelaporan dari instansi yang bertanggung jawab di bidang ketenagakerjaan kabupaten kota tempat pemborongan pekerjaan dilaksanakan mengenai jenis pekerjaan penunjang yang akan diserahkan,

b. Pencabutan izin operasional perusahaan penyedia jasa pekerja oleh instansi yang bertanggung jawab di bidang ketenagakerjaan provinsi berdasarkan rekomendasi dari kabupaten kota dalam hal : perusahaan penyedia jasa pekerja tidak mendaftarkan perjanjian penyedia jasa pekerja kepada instansi yang bertanggung jawab di bidang ketenagakerjaan kabupaten kota tempat pekerjaan dilaksanakan dan perusahaan penyedia jasa pekerja yang tidak mencatatkan perjanjian kerja kepada instansi yang bertanggung jawab di bidang ketenagakerjaan kabupaten kota tempat pekerjaan dilaksanakan.

c. Perubahan hubungan kerja dari PKWT menjadi PKWTT antara perusahaan penyedia jasa pekerja dengan pekerja sejak ditandatanganinya perjanjian kerja yang tidak memenuhi persyaratan Pasal 28 dan Pasal 29 Permenakertrans No.19/2012 tentang syarat-syarat penyerahan Universitas Pendidikan Ganesha| 66 
sebagaian pelaksanaan pekerjaan kepada perusahaan lain.

Dalam Permenakertrans No.19/2012 dan SE Menakertrans No.04/2013 diatur beberapa jenis sanksi dan atau akibat hukum apabila terjadi pelanggaran. Pada kondisi terjadi ketidakpatuhan perusahaan outsourcing untuk mengatur klausul pengalihan perlindungan pekerja dalam perjanjian kerja dengan pekerja yang didasarkan pada PKWT sesuai dengan amanat Putusan MK dan aturan pelaksananya perjanjian kerja tersebut secara otomatis akan atau harus beralih menjadi perjanjian kerja dalam bentuk PKWTT. Ketentuan tersebut dianggap sangat lemah untuk memaksa perusahaan outsourcing untuk menerapkan prinsip pengalihan perlindungan pekerja dalam perjanjian kerja mereka. Akibat hukum tersebut tidak secara substansial mampu memaksa perusahaan karena bila dipaksakan pada kondisi terburuk jika perusahaan tidak kuat secara finansial dan bangkrut maka yang dirugikan kembali adalah pihak pekerja. Pengaturan yang tegas mengenai sanksi, konsekuensi atas pelanggaran dan penegakan hukum atas pelanggaran menjadi sangat diperlukan agar prinsip ini dapat memberikan perlindungan hukum secara represif dalam rangka melindungi hak-hak pekerja.

\section{Penutup}

Berdasarkan

uraian permasalahan yang telah dibahas, maka dapat ditarik kesimpulan yakni :

Bahwa terdapat beberapa ketentuan dalam Permenakertrans RI No.19 Tahun 2012 dan SE Jurnal Komunikasi Hukum
Menakertrans

RI No.04/MEN/VIII/2013 yang secara substansial tidak sinkron dengan semangat dari Putusan MK No.27/PUUIX/2011 khususnya terkait upaya peningkatan perlindungan hukum terhadap pekerja outsourcing. Beberapa ketentuan Permenakertrans No.19/2012 dan SE Menakertrans No.04/2013 yang cenderung melemahkan adopsi dari penguatan perlindungan pekerja tersebut, diantaranya meliputi : bagian konsideran dengan tidak dicantumkannya Putusan MK sebagai landasan pembentukan Permenkertrans, bagian substansi pasal-pasal seperti pengaturan prosedur dan syarat-syarat penyerahan pekerjaan kepada perusahaan lain, kewenangan asosiasi sektor usaha, status badan hukum perusahaan, mekanisme pendaftaran perusahaan, ketidakjelasan pengaturan mengenai pesangon hingga pengaturan ketentuan mengenai sanksi yang dianggap tidak tegas.

\section{Saran}

Berdasarkan kesimpulan yang telah diuraikan diatas, maka saran yang dapat diberikan ialah :

Pemerintah seharusnya dapat membentuk suatu peraturan pelaksanaan yang memiliki sinkronsasi yang kuat terhadap semangat Putusan MK No.27/PUU-IX/2011, karena pengadopsian konsep peningkatan perlindungan hukum terhadap pekerja outsourcing secara utuh kedalam aturan pelaksana pasca Putusan MK dipastikan tidak akan mampu mencapai hasil maksimal tanpa didukung sinkronisasi pengaturan Universitas Pendidikan Ganesha| 67 
pada ketentuan-ketentuan pelaksana terkait lainnya.

\section{Daftar Pustaka}

Buku- Buku

Chandra Suwondo, 2003, Outsourcing Implementasi di Indonesia, Gramedia, Jakarta.

Hardijan Rusli, 2003, Hukum Ketenagakerjaan, Ghalia Indonesia, Jakarta.

Muhammad Aditya Warman, 2013, Business Process of Outsourcing Management, PT.Pusat Studi Apindo, Jakarta.

Richardus Eko Indrajit, 2003, Proses Bisnis Outsourcing, Grasindo, Jakarta.

\section{Jurnal/Makalah}

I Ketut Markeling, 2009, Existensi Outsourcing Dalam UndangUndang Nomor 13 Tahun 2003 Tentang Ketenagakerjaan, Kertha Pratika, Majalah Fakultas Hukum Universitas Udayana, Denpasar.

I Dewa Gede Palguna, 2012, Outsourcing Dalam Pandangan Mahkamah Konstitusi, Catatan Terhadap Putusan MK Nomor 27/PUU-IX/2011, Makalah yang disampaikan pada seminar oleh Bagian Hukum Internasional Fakultas Hukum Universitas Udayana dalam rangka pengabdian masyarakat, Gianyar, 9 Oktober 2012.

\section{Internet}

Andari Yurikosari, "Putusan Mahkamah Konstitusi Nomor 27/PUUIX/2011 Tentang Pekerja Outsourcing, Quo Vadis Bagi Para Pihak dalam Hubungan Kerja",

Jurnal Komunikasi Hukum www.pemantauperadilan.com, diakses tanggal 2 Maret 2016

Feryanto Hadi, "Permenakertrans Nomor 19 Tahun 2012 Lindungi Hak Pekerja", http://www.tribunnews.com, diakses pada tanggal 10 Maret 2016.

"Apa Itu Outsourcing", http:// www.sourcing.com, diakses tanggal 10 Maret 2016.

Juanda Pangaribuan, "Membaca Muatan dan Implikasi Permenaker Outsourcing", http//:www.pemantaukeadilan. com, diakses pada tanggal 12 Maret 2016.

Hadi Shubhan, "Kebijakan Oplosan Outsourcing Pekerja", http://www.jawapos.com diakses pada tanggal 12 Maret 2016.

Disnakertras Kalimantan Timur, "Penerapan Outsourcing Pasca Dikeluarkannya

Permenakertrans No.19 Tahun 2012",

http://disnakertrans.kaltimprov .com diakses tanggal 20 Maret 2016.

\section{Peraturan Perundang-Undangan}

Undang-Undang No.13 Tahun 2003 Tentang Ketenagakerjaan, Lembaran Negara Republik Indonesia Tahun 2003 Nomor 39.

Putusan Mahkamah Konstitusi Nomor.27/PUU-IX/2011.

Peraturan Menteri Tenaga Kerja Dan Transmigrasi Republik Indonesia Nomor: 19 Tahun 2012 Tentang Syarat-Syarat Penyerahan Sebagian 
Pelaksanaan Pekerjaan Kepada Perusahaan Lain.

Surat Edaran Menteri Tenaga Kerja Dan Transmigrasi Republik Indonesia Nomor: SE.04/MEN/VIII/2013 Tentang Pedoman Pelaksanaan Peraturan Menteri Tenaga Kerja Dan Transmigrasi Republik Indonesia Nomor 19 Tahun 2012 Tentang Syarat-Syarat Penyerahan Sebagian Pelaksanaan Pekerjaan Kepada Perusahaan Lain.

\section{Kamus}

Briyan A Garner, 2004, Black's Law Dictionary, West Publishing Co, United States of Amerika. 